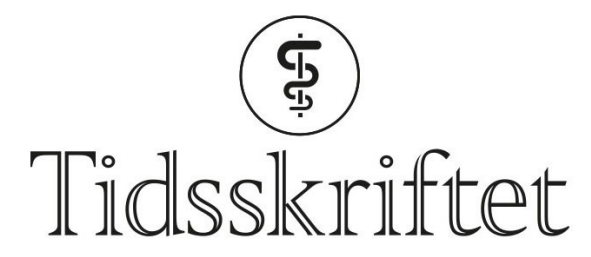

DEN NORSKE LEGEFORENING

\title{
Sjanse eller risiko?
}

SPRÅKSPALTEN

\section{ERLEND HEM}

E-post: erlend.hem@medisin.uio.no

Erlend Hem er professor dr.med., fagsjef og redaktør for Tidsskriftets språkspalte.

En kanadisk tv-stjerne tok nylig et oppgjør med hvordan man omtaler Downs syndrom. Sakens kjerne var skillet mellom sjanse og risiko.

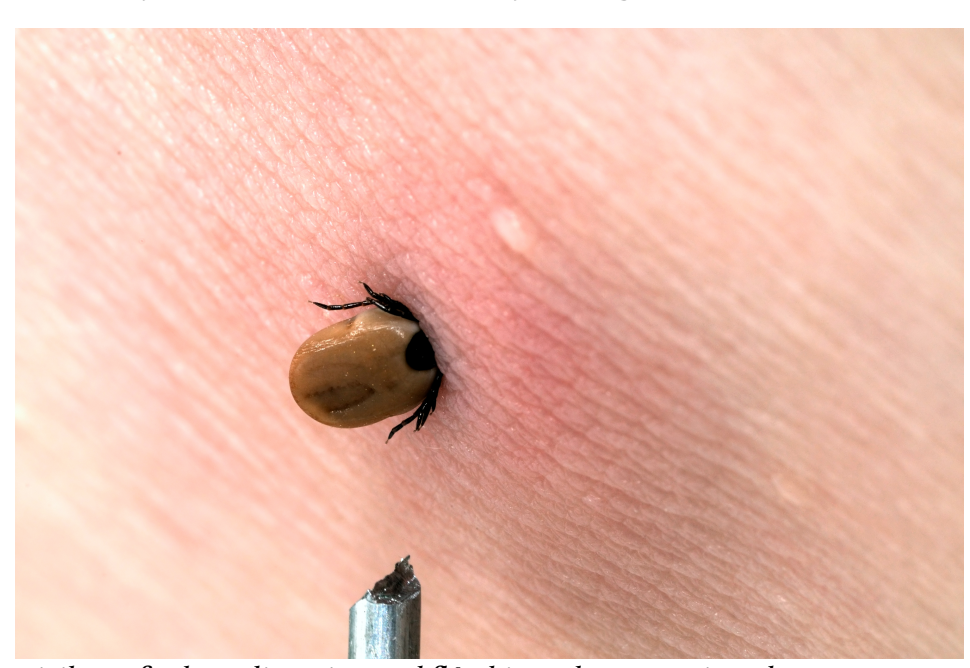

Risikoen for borreliasmitte ved flåttbitt er lav. Foto: iStock

Den kanadiske skuespilleren Caterina Scorsone, best kjent fra rollen som legen Amelia Shepherd i sykehusserien Grey's Anatomy, er mor til to jenter på seks og to år. Den yngste jenta er født med Downs syndrom, ifølge VG (1). Nylig postet tv-stjernen en melding som avisen refererte:

Én av 7oo babyer blir født med Downs syndrom. Ordbruk er viktig. Foreldre har ikke én til 700 «RISIKO» for å få et barn med Downs syndrom. Foreldre har én til 70o SJANSE for å få et barn med Downs syndrom. Akkurat som de har 50 prosents SJANSE for å få en jente eller en gutt (med noen vakre variasjoner også blant dem).(1)

Både sjanse og risiko betegner en mulighet. Men det er forskjell på dem. Sjanse antyder at muligheten er tiltalende, risiko at den er urovekkende (2). Sjanse brukes altså der det er mulighet for noe godt, for eksempel sier vi sjanse for helbredelse. Når det er mulighet for noe vondt, bruker vi risiko, for eksempel risiko for lungekreft $(3,4)$. Noen ganger kan det være nyttig å bruke mer nøytrale uttrykk, som for eksempel mulighet for, utsikt til eller sannsynlighet for.

Distinksjonen mellom sjanse og risiko er under press og har vært det lenge (5). Et blikk på aviser og nettsteder viser at mange gjør feil (ramme). I eksemplene i rammen burde det 


\section{Eksempler fra aviser og nettsteder}

«(...) sjansen for at to barn døde i krybbedød var 1 på 73 millioner» «Guttebarn (...) fikk halvert sjansen for å få misdannelser i penis» «Sjansen for å bli skadd eller omkomme i en arbeidsulykke er størst nettopp nå» «(...) sjansen for borreliosesmitte etter et flåttbitt er på bare to prosent» «Når en bikker 35 år, begynner sjansen for ikke å kunne få barn på naturlig måte å øke» «Ny studie: Rengjør du hendene slik, minsker sjansen for å bli syk» «Røyking øker sjansen for lungekreft»

Feilen finnes av og til i medisinske manuskripter også. Det er i grunnen rart, ettersom det $\mathrm{i}$ medisinen oftest er klart om et utfall er positivt eller negativt, og medisinere er vant til å forholde seg til risikobegrepet.

Siden feilen er så vanlig, kan man lure på om dette skillet mellom sjanse og risiko kommer til å bli borte. Svaret er antakelig ja. At sjanse kan bety 'risiko', står i flere ordbøker allerede (6-8). Men inntil videre får vi klare å holde styr på det. Vanskelig er det jo ikke.

\section{LITTERATUR:}

1. Ighanian CG. «Grey’s Anatomy»-stjerne hyller datter med Downs syndrom. VG 3.10.2018. http://www.vg.no/rampelys/tv/i/3jbnKq/grey-s-anatomy-stjerne-hyller-datter-med-downs-syndrom (22.1.2019).

2. Vinje FE. Moderne norsk. 5. utg. Oslo: Fagbokforlaget, 2002: 146.

3. Språkrådet. Feil bruk av ord og uttrykk. Skriveråd. https://www.sprakradet.no/sprakhjelp/Skriverad/Feil-bruk-av-ord-og-uttrykk/\#r (22.1.2019).

4. Risiko, sjanse. Forfatterveiledningen. Tidsskrift for Den norske legeforening. https://tidsskriftet.no/annet/ordliste (22.1.2019).

5. Redaksjonen. Sjanse for helbredelse og risiko for residiv. Tidsskr Nor Legeforen 1992; 112: 259.

6. Sjanse. I: Norsk ordbok: ordbok over det norske folkemålet og det nynorske skriftmålet. https://no2014.uib.no/perl/ordbok/no2014.cgi?soeksjanse (22.1.2019).

7. Sjanse. I: Det norske akademis ordbok. https://www.naob.no/ordbok/sjanse_2 (22.1.2019).

8. Sjanse. I: Stor norsk ordbok. https://www.ordnett.no/search?languageno\&phrasesjanse (22.1.2019).

Publisert: 7. mars 2019. Tidsskr Nor Legeforen. DOI: 10.4045/tidsskr.19.0068

(C) Tidsskrift for Den norske legeforening 2020. Lastet ned fra tidsskriftet.no 